\title{
Morphological Abnormalities and Dwarfism in Maastrichtian Foraminifera from the Cárdenas Formation, Valles-San Luis Potosí Platform, Mexico: evidence of paleoenvironmental stress
}

\author{
Lourdes Omaña $a^{1, *}$, Gloria Alencáster², José Ramón Torres Hernández ${ }^{3}$, Rubén López Doncel ${ }^{3}$ \\ ${ }^{1}$ Posgrado en Ciencias de la Tierra, Instituto de Geología, Universidad Nacional Autonóma de México, Ciudad Universitaria, \\ Coyoacán, C.P. 04510, México, D.F \\ ${ }^{2}$ Instituto de Geología, Universidad Nacional Autonóma de México, Ciudad Universitaria, Coyoacán, C.P. 04510, México, D.F. \\ ${ }^{3}$ Instituto de Geología, Universidad Autónoma de San Luis Potosí, Av. Dr. Manuel Nava 5, C.P. 78240, San Luis Potosí, S.L.P. \\ *lomanya@geologia.unam.mx
}

\begin{abstract}
During the early Maastrichtian an assemblage rich in large foraminifera, mostly composed of orbitoidal foraminifera, developed in the shallow-water deposits of the Cárdenas Formation (Valles-San Luis Potosí Platform, Mexico). Among them, the most abundant is Lepidorbitoides minima, some of which display a morphologically abnormal test consisting of polyvalent forms, conical tests and budding, which could be induced by abrupt changes in environmental factors. The occurrence of the abnormalities preceded the demise of this species and of all the larger foraminiferal association in the upper part of the Gansserina gansseri Zone (early Maastrichtian). The abnormalities could be induced by environmental stress, probably related to interplay of different events such as increased terrigenous input and the transition to deeper facies due to Laramide tectonic instability before the K/P boundary.

A late Maastrichtian community of dwarfed planktic foraminifera composed of Trinitella scotti Brönnimann, Plummerita reicheli Brönnimann, Rugoglobigerina cf. macrocephala Brönnimann, Rugoglobigerina hexacamerata Brönnimann, Heterohelix punctulata (Cushman), Pseudoguembelina costulata (Cushman), Pseudotextularia intermedia de Klasz, Globigerinelloides asperus Bolli, Guembelitria cretacea Cushman, Rugoglobigerina rugosa (Plummer), Rugotruncana sp., Globotruncanita stuarti (de Lapparent), and Globotruncana arca (Cushman) developed in the upper part of the sequence. This uncommon morphology could also be related to the highly stressed paleoenvironmental conditions related to global climatic change and local tectonic activity. Associated with this planktic assemblage is a deeper-water dwarfed benthic foraminiferal community composed of Gyroidinoides nitidus (Reuss), Coryphostoma incrassata (Reuss), Pseudouvigerina plummerae Cushman, P. cretacea Cushman, Bolivina cretosa Cushman, Planulina texana Cushman and Cibicides harperi (Sandidge).
\end{abstract}

Keywords: Abnormal foraminifera tests, Lepidorbitoides minima, dwarfed planktic foraminfera, Maastrichtian, Cárdenas Formation, Valles-San Luis Potosí Platform.

\section{Resumen}

Durante el Maastrichtiano temprano una asociación rica en macroforaminiferos compuesta principalmente de formas orbitoidales, se desarrolló en los depósitos de agua somera de la Formación Cárdenas (Plataforma Valles-San Luis Potosí, México). Entre ellos el más abundante es Lepidorbitoides minima, algunos individuos de esta especie presentan una concha morfológicamente anormal que consiste en formas polivalentes, conchas cónicas y la formación de protuberancias, las cuales pudieron ser inducidas por abruptos cambios ambientales. La presencia de las anormalidades precede a la desaparición de esta especie y de toda la asociación de macroforaminiferos en la parte superior de la Zona de Gansserina gansseri (Maastrichtiano temprano). Las anormalidades pudieron 
ser inducidas por estrés ambiental probablemente relacionado con diferentes eventos como un aumento en el aporte de terrigenos y la transición a facies más profundas debido a la inestabilidad tectónica laramídica antes del límite K/P.

Además, una comunidad de Maastrichiano tardio compuesta de especímenes de foraminiferos planctónicos enanos formada por Trinitella scotti Brönnimann, Plummerita reicheli Brönnimann, Rugoglobigerina cf. macrocephala Brönnimann, Rugoglobigerina hexacamerata Brönnimann, Heterohelix punctulata (Cushman), Pseudoguembelina costulata (Cushman), Pseudotextularia intermedia de Klasz, Globigerinelloides asperus Bolli, Guembelitria cretacea Cushman, Rugoglobigerina rugosa (Plummer), Rugotruncana sp., Globotruncanita stuarti (de Lapparent) y Globotruncana arca (Cushman) se desarrolló en la parte superior de la secuencia. Esta morfología no común pudiera también estar relacionada a condiciones paleoambientales estresantes relacionadas cambio climático global y a la actividad tectónica local. Asociado con este conjunto de foraminíferos planctónicos se observó una comunidad de foraminíferos bentónicos enanos de agua más profunda compuesta de Gyroidinoides nitidus (Reuss), Coryphostoma incrassata (Reuss),

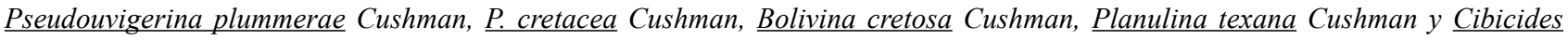
harperi (Sandidge).

Palabras clave: Concha anormal de foraminiferos, Lepidorbitoides minima, planctónicos enanos, Maastrichtiano, Cárdenas Formation, Platforma Valles-San Luis Potosí.

\section{Introduction}

Benthic foraminifera are indicators of enviromental changes in a wide range of marine enviroments (Fontalini and Coccioni, 2008) due to their short life cycle from a few weeks for the small taxa to one year for some larger forms (Boltovskoy, 1965; Murray, 1991), high diversity, and specific environmental requirements.

Many analyses of modern benthic foraminifera have been carried out in areas exposed to different kinds of stress. It is evident from these analyses that benthic foraminifera respond to adverse ecological conditions with abnormal growth such as reduced shell size, aberrant chamber shape, disturbed chamber arrangement, additional chambers, undeveloped test, and siamese twins (Coccioni, 2000; Geslin et al., 2000).

Recent studies have extensively documented foraminiferal test deformities from areas contaminated by heavy metals or other chemicals due to domestic sewage, and/or hydrocarbon spills (Resig, 1960; Alve, 1991; Yanko et al., 1998; Geslin et al., 1998; Samir, 2000; Geslin et al., 2002, Vilela et al., 2004; Buzas-Stephens and Buzas, 2005; Meriç et al., 2005; Cevison and Hallock, 2007; Luciani, 2007; Fontalini and Coccioni, 2008; Polodova and Schönfeld, 2008; Madkour and Ali, 2008; Debenay et al., 2009; Martínez-Colón et al., 2009). However, it is important to emphasize that anthropogenic pollution is not always the cause of abnormal test formation (Stouf et al., 1999a). Boltovskoy et al. (1991) stated that these abnormalities are related to natural environmental factors such as changes in temperature, reduced or elevated salinity, lack or overabundance of food, low dissolved oxygen content, substrate type, or insufficient light.

Morphological abnormalities in fossil foraminifera have been noted since the 1800s (Carpenter, 1856; Amicis, 1895; Rhumbler, 1902). Later, other researchers also reported on deformed foraminiferal tests in fossil assemblages (Pflum and Frerichs, 1976; Cann and De Deckker, 1981; Caralp,
1989) in different stressed environments which may be due, for instance, to depth-temperature, hypersalinity, and the increased supply of altered organic matter. Recently, Ballent and Carignano (2008) observed deformities in Late Cretaceous to early Paleocene benthic foraminifera in northern Patagonia, Argentina.

Test deformities in larger benthic foraminifera have also been recorded in fusulinids (Bradley, 1956; Wilde, 1965). Also, Nguyen (1980) observed that Lepidolina multiseptata presents two or more apertures in the proloculus. This indicates that during schizogony, two or more schizonts fused and grew together, forming a common test. This low number of tests restricted the propagation of the species.

Butterlin (1971, p. 23) reported teratological individuals of Lepidocyclina (Pliolepidina) pustulosa containing two embryons, with double growth of the equatorial layer from a location in Margarita Island (Punta Mosquito Formation) in Venezuela.

Görmüs and Meriç (2000) reported an early Maastrichtian orbitoidal foraminiferal assemblage from Turkey that shows unusual characteristics including lateral chambers within the embryo, teratological individuals (polyvalence), equatorial chamber growth, and conical forms. Kaya (2005) recorded teratological individuals of Omphalocyclus macroporus and the genera Discocyclina, Nummulites, and Lepidocyclina at several locations in Turkey.

Planktic foraminifera also have developed abnormal forms. Gerstel et al. (1986) recorded a large population of aberrant Parvularugoglobigerina eugubina and Eoglobigerina in the basal Danian from DSDP Site 577 (Shatsky Rise, North Pacific). They observed forms characterized by the development of secondary apertures, bullae, and abnormal final chambers. These abnormal morphotypes are considered to be ecophenotypic variants reflecting ecologic stress or instability in earliest Cenozoic marine environments.

Coccioni and Luciani (2006) described Gumbelitria irregularis from the $\mathrm{K} / \mathrm{T}$ boundary that displays aberrant 
tests with irregular chambers.

Deformities in mid-Cretaceous planktic foraminifera have also been documented by Venturati and Baudin (2007), who reported teratological tests from the Albian Pialli Level (= Breistroffer level, OAE1D) in Monte Petrano, Italy, as evidence of paleoenvironmental perturbations related to a period of anoxia. Venturati (2007) stated that planktic foraminifera from the Cretaceous and early Danian with twin, bilobated or additional chambers in the last whorl may be potential proxies of paleoenvironmental perturbations.

We follow Stouff et al. (1999b), who recommend the use of the term "deformations" to describe abnormalities formed by modification of the living foraminifer tests and the term "malformations" for abnormalities resulting from an anomaly in the ontogenetic development process. When the origin of the abnormality is not evident, "morphological abnormalities" or "abnormal tests" can be used.

With respect to the planktic dwarfism, Keller and Abramovich (2009) indicate that the planktic foraminiferal size reduction is associated with high-stress environments such as greenhouse warming, mesotrophic or restricted basins, shallow marine marginal settings, and volcanically active regions. The volcanism during the late Maastrichtian appears to have been the primary cause for the climate change, including greenhouse warming and associated global stress-induced species dwarfing (Abramovich and Keller, 2002).

The objectives of this paper are to document the morphologically abnormal tests of Lepidorbitoides minima from the Cardenas deposit, which could be related to environmental stress in early Maastrichtian, and its subsequent disappearance due to major environmental changes. We have also analyzed the planktic foramininiferal assemblage of late Maastrichtian age from the same area. The planktic foraminifera show a size reduction that reveals the persistence of a high stress environment.

\section{Geographical and geological setting}

The Cárdenas Formation is an Upper Cretaceous sedimentary sequence, about $1000 \mathrm{~m}$ thick, that consists of shallow water fine siliciclastic sediment with some interlayed limestone beds. The formation is exposed in an asymmetric syncline of the folded Sierra Madre Oriental.

The Cárdenas Formation crops out close to the town of Cárdenas in the state of San Luis Potosí, Mexico (Figure 1). The Cárdenas Formation is located in the Gulf of México Province, where tectonic evolution is dominated by passive margin development associated with the opening of the Gulf of Mexico, and overprinted by Laramide orogenic effects. Stratigraphic evolution during the Late Jurassic to Early Cretaceous was dominated mostly by eustasy during the Late Jurassic to Early Cretaceous. From the end of the Cenomanian through the Maastrichtian, however paleogeography and facies relations drastically changed as

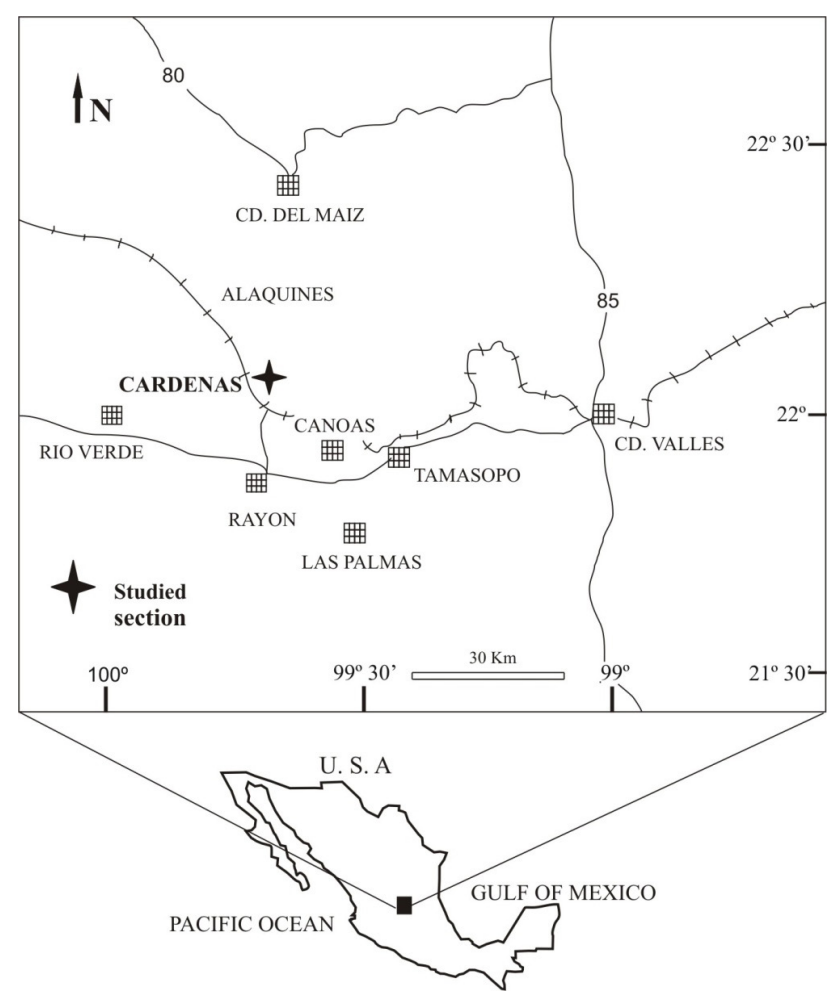

Figure 1. Geographic map of the study area showing location of measured section.

the result of diachronous Laramide Orogeny (Goldhammer and Johnson, 1999). The Cárdenas Formation overlies the El Abra Formation and it is unconformably overlain by the Tabaco Formation, an early Cenozoic unfossiliferous terrigenous sequence (Myers, 1968; Schafhauser et al., 2007).

\section{Material and Methodology}

The samples used in this study come from a section measured and sampled east of the town of Cárdenas, close to the Cárdenas-Tampico railway (Figure 2). The material includes limestone samples that were examined by means of thin sections in order to view the structural morphology of the larger foraminifera and to analyze the test changes. The shaly samples were processed following the standard method for foraminiferal recovery. The samples were then washed repeatedly in water and passed through a $63 \mu \mathrm{m}$ screen. The washed residue was dried and the foraminifera separated and identified. The benthic and planktic foraminifera were illustrated by SEM photos.

\section{Stratigraphy}

The Cárdenas Formation accumulated in an environmental system controlled by regional tectonics, 


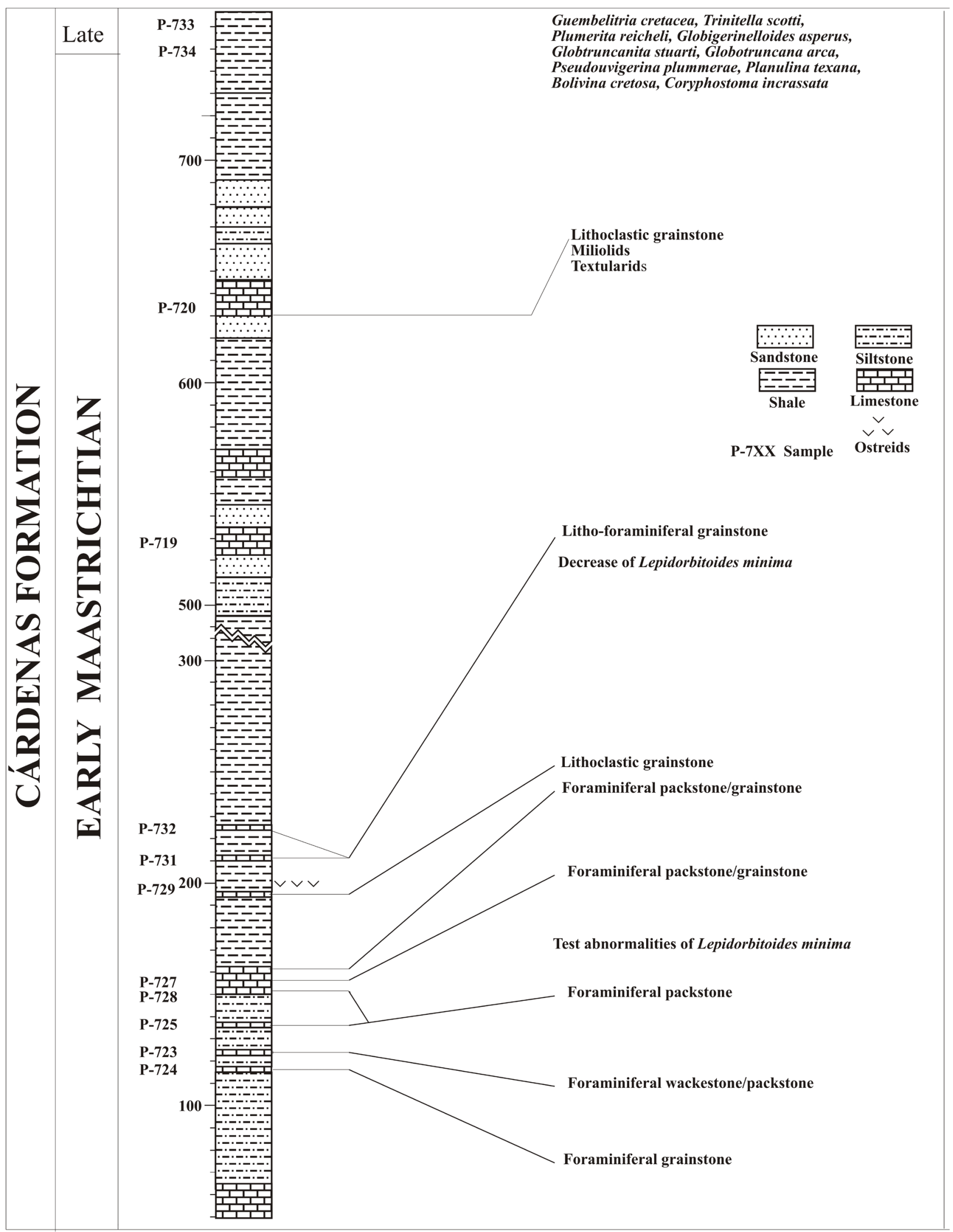

Figure 2. Lithologic column of the Cárdenas Formation 
climate, hydrological conditions, terrigenous input and carbonate production (Myers, 1968; Schafhauser et al., 2007).

In the studied section, the unit consists of alternating siliciclastics and limestones, which are not rhythmically bedded (Figure 2). Its basal contact with the El Abra Limestone is unconformable. The basal part of the Cárdenas Formation is composed of rudist-limestone and a terrigenous sediment sequence, and is probably related to slow transgression (Figure 2). This transgression is associated with internal cycles which permitted the production of carbonates if the platform remained within the photic zone. Eventually deposition caught up with the newly created accomodation space as the rising base level decelerated and the transgression gave way to highstand normal regression.

The overlying Cárdenas carbonate deposit could be related to highstand conditions, which are most favorable to the development of carbonate systems on the platform. The highstand system marks the platform progression that corresponds to the development of a variety of carbonate facies where a great number of larger foraminifera occurs associated with an abundant invertebrate association, including bryozoans, corals, gastropods, bivalves, worm tubes, and coralline red algae (Samples P-723, P-724, P-725, P 727, P728; Figure 3.2).

Up section an unfossiliferous grainstone is followed by bioaccumulations of ostreids (Arctostrea aguilerae and Exogyra costata), which indicate a considerable siliciclastic influx and a decrease in fauna diversity. This interval is probably related to a Laramide tectonic pulse that activated the source-area, depositing the terrigenous sediment.

The overlying foraminiferal grainstone contains a different foraminiferal association with planktic foraminifera and a lower abundance of Lepidorbitoides minima (Sample P-732; Figure 3.1). This unit represents continued highstand conditions and marks the switch to mixed carbonatesiliclastic deposits.

Upward a package of shale intercalated with rudist limestone is also recognized as a highstand cycle (Samples P-719, P-720). Overlying the carbonate units is a clastic unit that contains dwarfed planktic foraminifera and a deeper benthic foraminiferal community. This unit represents drowning of the carbonate platform by a rapid transgression and high rate of base-level rise that probably resulted from the Laramide Orogeny.

Extensive data has been published previously for this section (Omaña et al., 2008) and the interpretation is based on the stratigraphic evolution of a carbonate platform that was drowned in the late Maastrichtian, as testified by the planktic foraminifera record. This interpretation differs from that of Schafhauser et al. (2007) who regarded the Cárdenas and Tabaco formations as a wave-dominated shorefacedelta system with a regression trend, which terminated in subaerial exposure of the area, as indicated by paleosoils in the red beds of the Tabaco Formation during the middle-late Maastrichtian.

\section{Depositional Environment}

The presence of rudists in the base of the Cárdenas section indicates a shallow-marine carbonate platform setting. A thick unfossiliferous siltstone overlies these carbonates.

When the terrigeous influx ceased, a variety of carbonate facies were deposited and faunal assemblages prospered in this environment. The presence of a great number of larger foraminifera associated with bryozoans, corals, gastropods, bivalves, worm tubes, and coralline red algae are recorded. The high diversity faunal association and the packstone, wackestone/packstone and grainstone textured-limestone suggest an open marine shallow water platform environment with changes in water energy (Omaña et al., 2008). In this interval we observed abnormal tests of Lepidorbitoides minima (Samples P-723, P-724, P-725, P 727, P728).

Higher in the section, an unfossiliferous grainstone is capped by bioaccumulations of ostreids (Arctostrea aguilerae and Exogyra costata) that, together with a decrease in fauna diversity, indicate a decrease in marine water depth.

The overlying limestone (foraminiferal grainstone) contains a different foraminiferal association composed of abundant Sulcoperculina globosa as well as Vaughanina barkeri with planktic foraminifera and a lower abundance of Lepidorbitoides minima (Sample P-732). The presence of planktic foraminifera as Gansserina gansseri, Contusotruncana $\mathrm{cf}$. walfischensis, Planoglobulina carseyae, Rugoglobigerina hexacamerata, and Guembelitria cretacea and the great quantity of red algae suggest a deepening depositional setting on the platform (Figure 3.1). Following this deepening, the platform shallowed as indicated by the occurrence of rudists (Samples P-729, P-732).

At the top of the section, the shale samples (P-733, P734) contain a different foraminiferal assemblage composed of a dwarfed planktic foraminifera community. The benthic foraminifera of this interval are represented by Gyroidinoides sp., Coryphostoma incrassata, Pseudouvigerina plummerae, P. cretacea, Bolivina cretosa, Planulina texana, Cibicides harperi, and Praebulimina carseyae, suggesting outer neritic setting depths (Culver, 2003; Keller, 2005).

\section{Age}

An early Maastrichtian age is assigned to the Cárdenas assemblage based on the planktic foraminiferal association, and the occurrence of the larger benthic foraminifer Lepidorbitoides minima (Alencáster et al., 1999; Omaña and Pons, 2000; Omaña et al., 2008). Ifrim et al. (2005) reported the presence of one specimen of ammonite species Pachydiscus neubergicus from the early Maastrichtian. The presence of age-diagnostic planktic foraminifers 

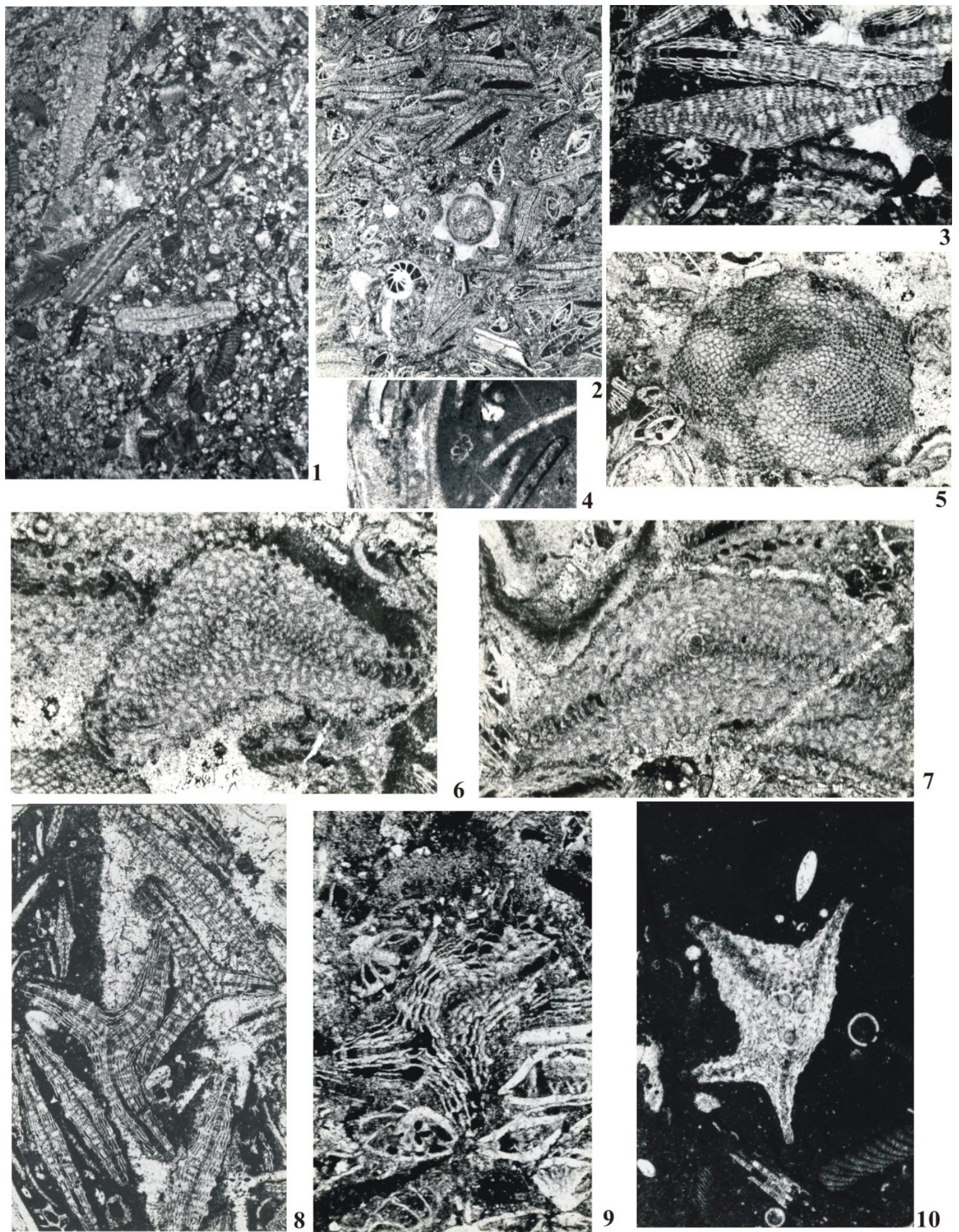

Figure 3. Larger Foraminifera (early Maastrichtian, Cárdenas Formation, Valles-San Luis Potosí Platform (Figures 1-9) and Angostura Platform (Figure 10) 1. Grainstone with abundant red algae and scarce Lepidorbitoides minima. (sample P-731) X18

2. Packstone-grainstone with a rich foraminiferal association composed of Lepidorbitoides minima, Sulcoperculina dickersoni, Ayalaina rutteni X10 (sample P-725).

3. Axial section of normal Lepidorbitoides minima showing the embryo (protoconch and deteroconch) X25 (sample P-726).

4. Axial section of Guembelitria cretacea ( sample P-723) X60.

5. Subequatorial section of normal Lepidorbitoides minima showing diamond shaped equatorial chambers, X16 ( sample P-728).

6, 7. Abnormal conical test of Lepidorbitoides minima X20, X30 (sample P-728, P725)

8. Lepidorbitoides minima polyvalent abnormal tests associated with normal flat shapes X16 (sample P-728).

9. Polyvalent forms with fusion of two individuals of Lepidorbitoides minima X16 (sample P-725).

10. Lepidorbitoides minima with several embryons inside test X 15 (sample EZ-1). 
Ganserina gansseri, Contusotruncana cf.C. walfischensis, Planoglobulina carseyae, Rugoglobigerina hexacamerata, and Guembelitria cretacea further constrains the section to the upper part of the planktic Gansserina gansseri Zone in the early Maastrichtian in the mid-member of the Cárdenas sequence (Figure 2).

Although Lepidorbitoides minima presents some evolutionary morphologic characteristics of late Campanian primitive forms, its association with the above planktic foraminifers indicates an early Maastrichtian age.

In addition, in the uppermost part of the studied section, another foraminiferal association is observed that consists of a group of dwarfed planktic foraminifera: Trinitella scotti, Plummerita reicheli, Heterohelix navarroensis, Rugoglobigerina hexacamerata, Rugoglobigerina macrocephala, Guembelitria cretacea, H. punctulata, Globigerinelloides asperus, Rugoglobigerina rugosa, Rugotruncana sp., and Globotruncana arca (Figure 2). A late Maastrichtian age is suggested based on the occurrence of Trinitella scotti, which makes its first appearance at the base of the late Maastrichtian Abathomphalus mayaroensis Zone (Longoria and Gamper, 1974; Premoli Silva and Sliter, 1995; Premoli Silva and Verga, 2004).

\section{Results}

\subsection{Foraminiferal assemblage}

The larger Orbitoidacea foraminifera were widely distributed during the Late Cretaceous due to broad environmental requirements (Fleury et al., 1985). They flourished before the K/P boundary and are important markers in biostratigraphy, as well as indicators of environmental conditions.

The foraminiferal assemblage from the Cárdenas Formation consists of abundant larger Orbitoidacea including Lepidorbitoides minima, Vaughanina barkeri, Sulcoperculina vermunti, S. dickersoni, and S. globosa, Ayalaina rutteni (Figures 3.2,4) and the opportunistic planktic Guembelitria cretacea, together with an invertebrate community composed of bryozoans, mollusks and serpulids.

\subsection{Morphological abnormalities of Lepidorbitoides minima}

Lepidorbitoides minima was described by Douvillé (1927) for the first time from the Cretaceous deposits that crop out on the railway between Cárdenas and Canoas (Km 419-420). This species is characterized by a flat lenticular test with orbitoidal coiling and the formation of equatorial and lateral chambers. The juvenarium is bilocular with a protoconch and deuteroconch enclosed by a thick wall. The equatorial layer is composed of spatulated to diamondshaped chambers interconnected by stolons that show a median dark line (Figure 3.5). In axial section, the test shows a bilocular embryonic apparatus with a layer of equatorial chambers covered by a thin layer of lateral chambers on both sides (Figure 3.3). We recorded only the megalospheric generation, which measured $1.6-3.6 \mathrm{~mm}$ in diameter.

In the studied material, test abnormalities were observed exclusively in the $k$-strategist Lepidorbitoides minima, which is the dominant species. Abnormalities are observed in only a relatively small percentage of the total number of individuals, varying from 10 to $13 \%$ (Figure 6). Abnormalities of the foraminifera test are developed either during the lifetime of the individual or as result of post mortem changes. The post mortem changes are: flattened, bioerosion, mechanical damage, production of holes and tunnels, and dissolution.

The morphological abnormalities observed in Lepidorbitoides minima from the Cárdenas samples have a paleoecological significance and could have been produced during the lifetime and growth period of these organisms. These abnormalities were mostly observed in axial sections.

\subsection{Conical forms}

Lepidorbitoides normally have a lenticular test, but we observed individuals that display a conical shape unlike the original flat test (Figures 3.6, 3.7). These forms have also been reported in Turkey (Görmüs and Meriç, 2000).

\subsection{Polyvalence}

Polyvalent forms have been interpreted as twin development and the result of ecological conditions during reproduction by a schizogonic parent (Neumann and Poisson, 1970: Meriç, 1970, 1973, 1992).

Polyvalence also refers to the formation of an accidental association between two or more embryonic apparati of the same generation (Gary et al., 1972).

Polyvalent individuals have been described as teratological forms (Meriç, 1979) that usually result when two or more individuals come together.

Polyvalent individuals (polyvalent test twins and triplets) with two or more megalospheric embryons probably belong to the same clone, with a common late growth stage. This is considered to be an accidental association, not related to gamontogamy (Hottinger, 2006 ).

In the Cárdenas samples, we observed polyvalent tests (Figure 3.8; Figures 4.1, 4.2, 4.3) with double embryonic apparati producing tests that could be the result of a reproductive disfunction that inhibited the separation of the specimens. Each embryo has its own equatorial and lateral chambers, forming an irregular test with a $\mathrm{Y}$ or $\mathrm{V}$ shape (Figure 4.1-6) or stellate forms (Figure 4.7). This is probably due to environmental conditions that disrupted schizogonic reproduction.

We report triangular tests with an unusually large proloculus that probably contained two embryonic apparati (Figure 4.5). In addition, we found a pyriform test with an 

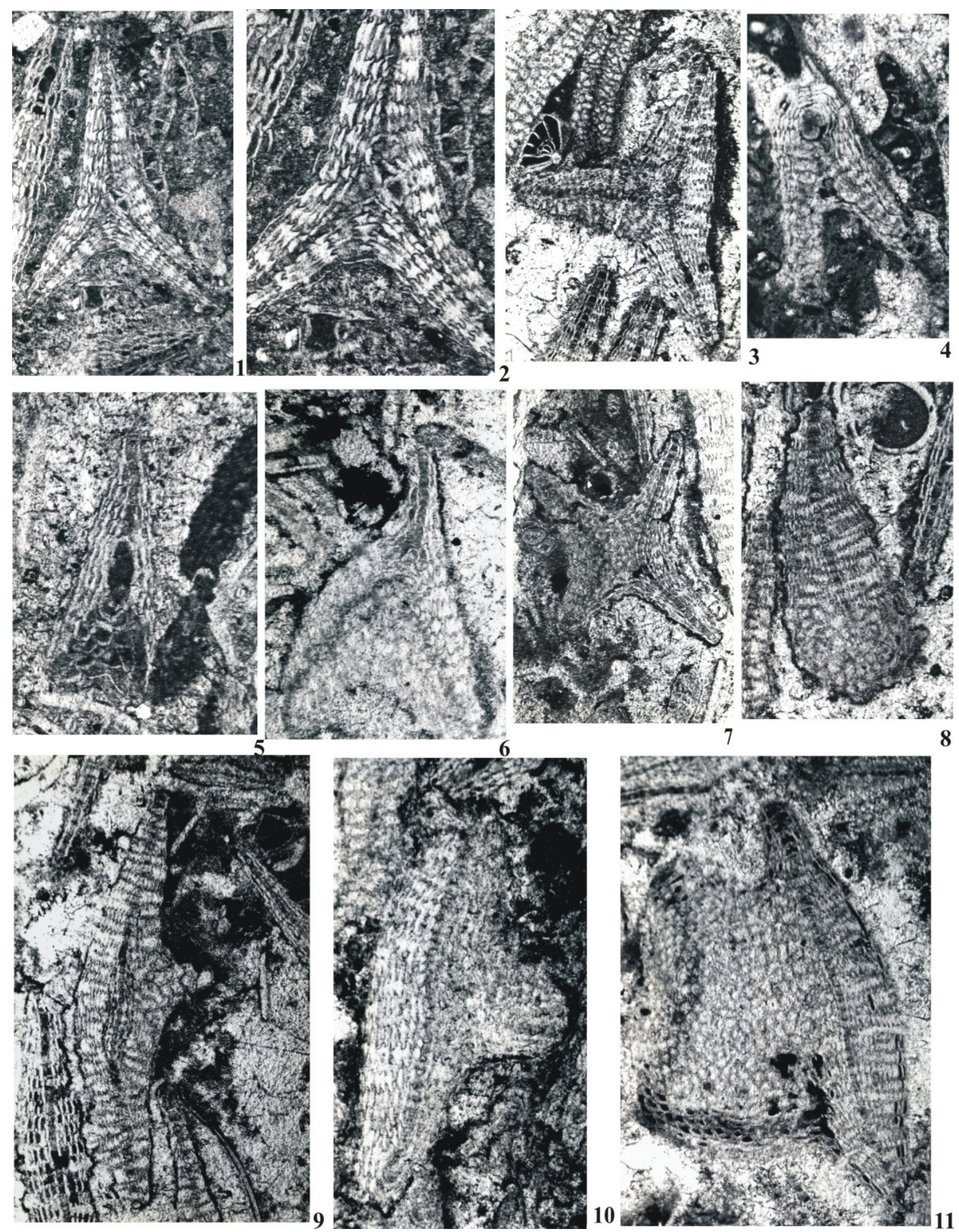

Figure 4. Axial sections of Lepidorbitoides minima (lower Maastrichtian Cárdenas Formation, Valles-San Luis Potosí Platform).

1, 2. Polyvalent test of Lepidorbitoides minima with two embryons X20, X40 (sample P-725).

3. Lepidorbitoides minima with two embryons forming a Y-shaped test X20 (samples P728).

4. Abnormal Lepidorbitoides minima showing V-shaped test X20 (sample P-723).

5, 6. Lepidorbitoides minima showing large embryon which also developed a polyvalent test X20 (samples P-727, P-723).

7. Abnormal Lepidorbitoides minima showing stellate-shaped test X30 (sample P-728).

8. Irregular proliferation of the lateral chambers forming a pyriform test X32 (sample P-728).

9, 10. Abnormal growth of lateral chambers in Lepidorbitoides minima producing a small or large protuberance X28, X35 (samples P-728, P-725)

11 Irregular growth of the lateral chambers producing a new test X20 (sample P-724). 
irregular proliferation of the lateral chambers (Figure 4.8).

One specimen of Lepidorbitoides minima has several embryos inside the test. (Figure 3.10). This form was found in the Angostura Platform (Chiapas, Mexico).

We also observed polyvalent complex tests produced by the fusion of two individuals (Figure 3.9).

\subsection{Budding of the lateral chambers}

An uncommon growth of the lateral chambers may have been produced by irregular growth and proliferation of the lateral chambers forming a small to large protuberance (Figure 4.9-10). Morphologically abnormal individuals display an irregular growth of the lateral chambers that forms a new test (Figure 4.11).

According to Boltovskoy et al. (1991) and Alve (1995), abnormalities may result from multiples effects. In our case, we speculate that the observed changes in Lepidorbitoides could be associated with temperature, salinity fluctuations and terrigenous input in an unstable environment related to global climatic variations and local Laramide Orogeny.

\subsection{Dwarfism of planktic foraminifera}

The size reduction, termed "Lilliput effect" by Urbanek
(1993), has been observed in many organisms, ranging from large mammals to invertebrates and to the smallest microscopic organisms. Invariably, size changes are associated with highly stressed environments. They represent a survival strategy often in the aftermath of mass extinctions and rarely with pre-extinction or other highly stress environments. However, the dwarfing in planktic foraminiferal species has recently been documented from upper Maastrichtian sediments of Israel, Egypt, Madagascar, and South Atlantic Site 525 (Abramovich et al., 1998, 2002; Abramovich and Keller, 2003; Keller, 2002, 2003, 2005).

Dwarfing is the most striking response to the abrupt warming and occurs in various species of different morphologies (biserial, trochospiral and keeled forms). In the Cárdenas Formation we observed dwarfed forms in the studied planktic foraminiferal assemblage including Trinitella scotti, Plummerita reicheli, Rugoglobigerina macrocephala, Rugoglobigerina hexacamerata, Heterohelix navarroensis, H. punctulata, Globigerinelloides asperus, Guembelitria cretacea, Rugoglobigerina rugosa, Rugotruncana sp, and Globotruncana arca (Figure 5).

On the other hand, Keller (2004, p. 66) indicates that surface-dwelling ecological specialists (small trochospiral species) of the Rugoglobigerina group (R. scotti, $R$. hexacamerata, $R$. hankkeninoides) are rare except during

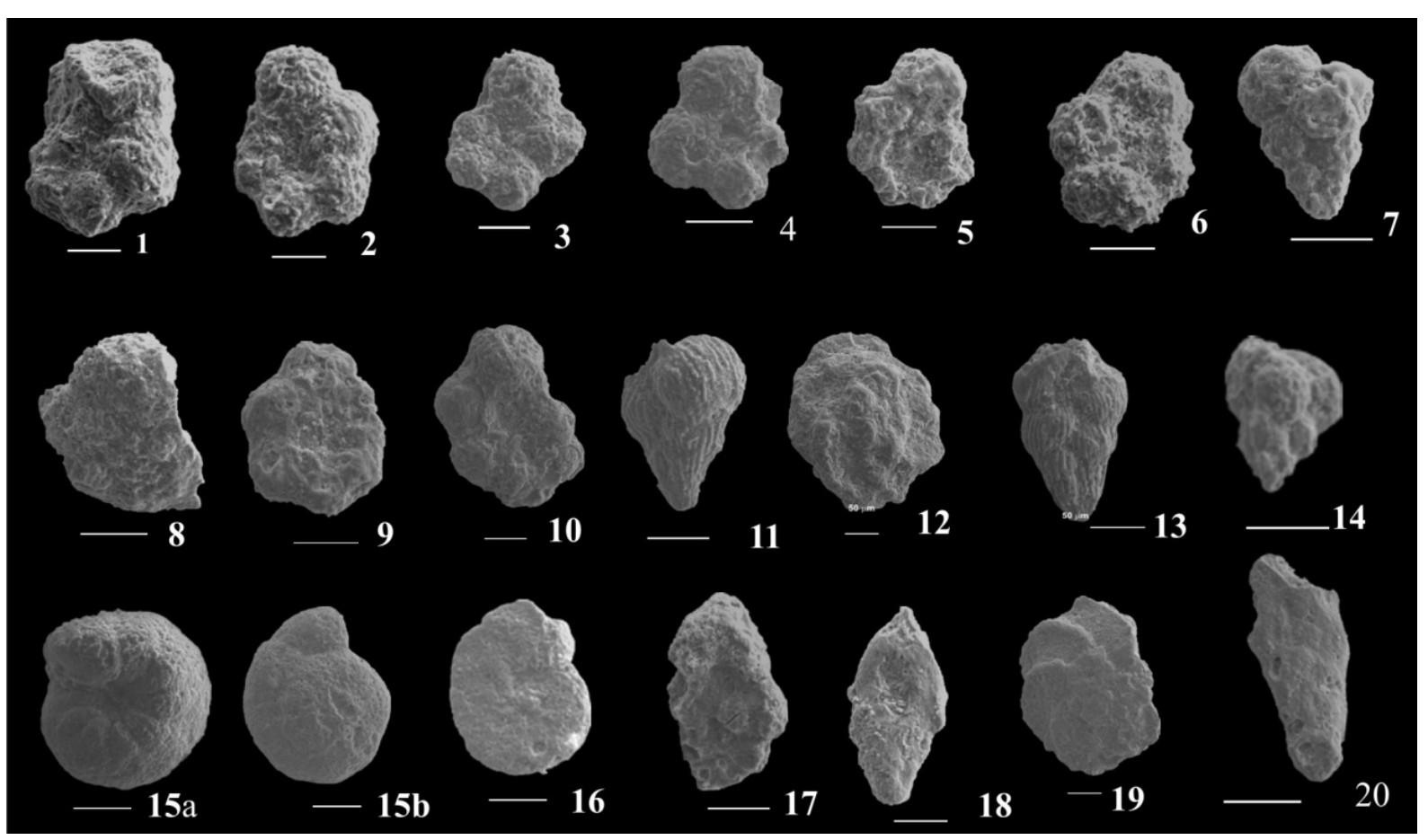

Figure 5. Dwarf planktic and benthic foraminifera (upper Maastrichtian, Cárdenas Formation, Valles-San Luis Potosí Platform).

1. Trinitella scotti (sample P734); 2. Rugotruncana sp. (sample P-734); 3. Plummerita reicheli (sample P-734); 4. Rugoglobigerina cf. R. macrocephala (sample P-734); 5. Globigerinelloides asperus (sample P-733); 6. Rugoglobigerina rugosa (sample P-733); 7. Heterohelix punctulata (sample P-733); 8. Plumerita reicheli (sample P-734); 9. Globotruncana arca (sample P-734); 10. Rugoglobigerina hexacamerata (sample P-734); 11. Pseudotextularia intermedia (sample P-734); 12. Globotruncanita stuarti (sample P-734); 13. Pseudoguembelina costulata (sample P-733); 14. Guembelitria cretacea (sample P-734); 15ab. Gyroidinoides sp. (sample P733); 16. Cibicides harperi (sample P-733); 17. Pseudouvigerina plummerae (sample P-733); 18. Bolivina cretosa (sample P-733); 19. Planulina texana (sample P-733); 20. Coryphostoma incrassata (sample P-733).

Scale bar $50 \mu \mathrm{m}$ 
the warming in Zone CF1, which reflect the global climate warming.

The dwarfed specimens are identical to normal sized specimens with fully developed of chambers, apertures, and surface ornamentation. These forms show a size diminution (Samples P-733, P-734) probably in response to a stressed environment during this time such as the extreme climate warming. At times of high environmental stress species diversity is reduced in low to middle latitudes, and in shallow shelf areas and restricted basins. Species reduction is selective, eliminating the largest and most specialized species: Racemiguembelina, Contusotruncana, and Planoglobulina (Keller and Abramovich, 2009) which could also be the result of an outer neritic environment as was also recorded by Keller (2004) in Israel (Mishor Rotem).

\section{Discussion}

In recent environments abnormal tests are up to $20 \%$ of the population in contaminated areas (Geslin et al., 1998), but elsewhere the percentage is lower, for example, $1-3 \%$ with a maximum of $7 \%$ (Alve, 1991), <10\% (Coccioni et al., 1997), 30\% (Lidz, 1965) and 3.5\% (Yanko et al., 1998). In the Maastrichtian fossil record of NE Turkey Inan et al. (1996) reported a different asexual reproduction phase in $65 \%$ of the individuals of Simplorbites papyraceus and only $8 \%$ of the specimens were normal specimens. Ballent and Carignano (2008) recorded abnormal tests in up to $74 \%$ of total Protoelphidium specimens of CampanianMaastrichtian age (northern Patagonia, Argentina), while in the studied material the abnormal tests of $k$-strategist Lepidorbitoides minima constitute a relatively small percentage: 10 to $13 \%$ (Figure 6 ) of the total number of foraminifera, which is similar to Recent examples.

In our material from the Cárdenas Formation the types of abnormal test morphology in Lepidorbitoides minima include conical tests, polyvalence and budding of lateral chambers.

Lepidorbitoides is characterized by a flattened test however some specimens display unusual conical shapes. We have suggested that these changes in test morphology

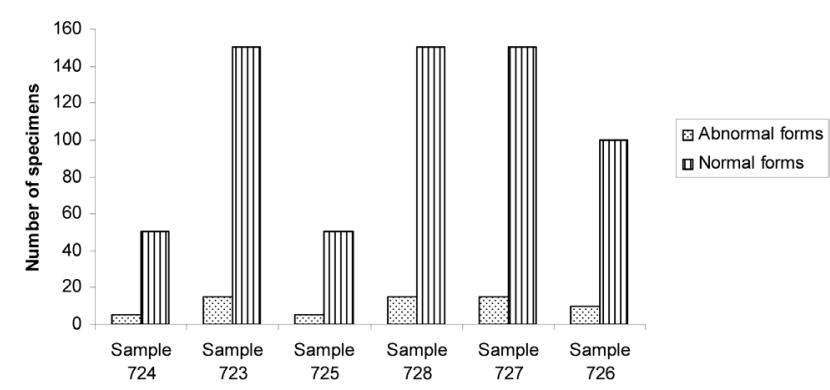

Figure 6. Graphic showing the number of the normal and the abnormal specimens of Lepidorbitoides minima in stratigraphic order. are the result of stress induced by changes in water energy (Omaña et al., 2008). In Turkey, Görmüs and Meriç (2000) also reported conical forms in Orbitoides sp. related to environmental conditions, such as strong currents.

The most common abnormality in Lepidorbitoides minima is the development of double tests, formed by double embryonic apparati which produced $\mathrm{Y}$ or $\mathrm{V}$ shaped tests of the same size (Figures. 3.8; 4.1-3; 4.5-7). Juveniles twinned specimens have also been recorded (Figure 3.9). These abnormalities have been observed repeatedly in the geological record.

Early joining of embryos or juveniles has been noticed in several species of recent foraminifera (Rhumbler, 1911; Le Calvez, 1938), and it was described from laboratory cultures (Myers, 1935 in Patellina corrugata). Double or triple embryos have been noted by various authors (Cole, 1960; Butterlin, 1971; Nguyen, 1980). Polyvalent individuals in fossil forms may have been capable of reproducing by schizogony (Meriç, 1964, 1970, 1973, 1979, Neumann and Poisson, 1970; Görmüs and Meriç, 2000; Kaya, 2005).

In laboratory cultures, double tests occur spontaneously, but are rarely found under normal saline conditions. On the contrary, they are quite common in hypersaline cultures. The hypersalinity would therefore facilitate the fusion of young after schizogony, suggesting that hypersalinity inhibits or slows down the movements of the young and reduces the dispersion of the juveniles, forming double or multiple tests with an abnormal morphology. Hypersaline environments could disturb pseudopod emission, so that the juvenile specimens slowly scatter after their release by the schizont (Stouff et al., 1999a).

Another hypothesis supposes that the thickness of the reproduction cyst could be higher in stressed conditions, such as hypersalinity. Such thicknesses may slow down the destruction of the cyst and therefore delay release of the young (Stouff et al., 1999a).

Eventually, when the cyst is broken, the young macrospheric embryos escape as twins and triplets, etc., developing together without any separation (Meriç, 1972, 1992).

In natural settings, the presence of double tests could be related to multiple environmental conditions such as light, temperature, salinity, $\mathrm{pH}$, turbidity, or the chemical composition of the water, which are factors that could disturb the reproductive process. Reproduction in larger benthic foraminifera is controlled by environmental factors. The optimal environmental conditions required for successful reproduction are very restricted compared to the optimum range for their survival (Bradshaw, 1955; Boltovskoy and Wright 1976; Nigam and Caron, 2000). For this reason, attributing these test abnormalities to a single cause is not easily accomplished. Nevertheless we speculate that the abnormalities in Lepidorbitoides minima could be associated with paleoecological changes such as temperature, salinity fluctuations and terrigenous input in an unstable environment where these organisms lived. The 
occurrence of abnormal forms preceded the diminution of this fossil and the demise of all larger benthic foraminifera in the early Maastrichtian (upper part of Gansserina gansseri Zone). The demise of all larger foraminifera in the studied locality was associated with major environmental global climatic changes ( $c f$. Barrera, 1994) and rises in sea level related to local tectonics during the Laramide Orogeny (Frank and Arthur, 1999).

The packstone-grainstone textured limestone and the fossil association suggest a warm shallow-water open marine platform environment where Lepidorbitoides minima was recorded (Figure 3.2) and the abnormal forms were observed (Figures 3.6-9; Figures 4.1-11).

In Europe, Orbitoides and Omphalocyclus probably lived in shallower water than Lepidorbitoides, but the ranges overlap (Van Goersel, 1978). Abramovich et al. (2002) reported that in the south of France and in the Subbetic Realm, southern Spain, Orbitoides is replaced by Lepidorbitoides in the lower part of the photic zone. Hottinger (1997) indicates a range of depths for Lepidorbitoides between 40 and $80 \mathrm{~m}$ in the upper photic zone and $80-140 \mathrm{~m}$ in the lower photic zone.

On the other hand, it is important to point out that we recorded a great abundance of megalospheric forms of Lepidorbitoides minima, suggesting that repeated asexual reproduction was probably induced by the stressful environment with the result of controlling the stability of the foraminiferal population. A similar trend has been observed by Harney et al. (1998), who suggested that repeated asexual reproduction may be an effective method of increasing population densities, while alternation of asexual and sexual generations is more common under favorable environmental conditions.

Previously, Rötger (1974) and Rötger et al. (1990) observed that a gamont of $H$. depressa produced solely schizonts (suggesting that no meiosis occurred in the parent), which could explain why most recent fossil assemblages are dominated by megalospheric individuals.

A late Maastrichtian, dwarfed planktic assemblage is composed of globotruncanids, rugoglobigerinids and opportunists.

High stress paleoecological conditions during the late Maastrichtian included rapid climate change, local tectonic changes and volcanism and have been reported in numerous environments.

Volcanism during the late Maastrichtian appears to have been the primary cause for climate change as greenhouse warming and associated global stress-induced species dwarfing (Keller, 2005). The biotic reactions of the high stress environment include the Lilliput effect or dwarfing (Keller, 2005).

The Lilliput phenomenon has been documented in several groups of marine and terrestrial organisms, in micro and macro-organisms (Brade and Twichett, 2009).

Wade and Olsson (2009) proposed the term "preextinction dwarfing" for size reduction in the interval prior to extinction, also considered to be a reaction to changing environmental conditions, in planktic foraminifera. This term refers specifically to a phenomenon preceding extinction, in contrast to the Lilliput effect, which is post extinction.

Our results suggest that the size diminution in planktic foraminifera occurred during the late Maastrichtian (lower part of the Abathomphalus mayaroensis) preceding the $\mathrm{K} / \mathrm{P}$ boundary. It could be related to major environmental factors including global climate changes characterized by extreme temperature and sea-level changes provoked by local tectonic changes (Laramide Orogeny).

\section{Conclusions}

Morphological abnormalities of Lepidorbitoides minima as well in the planktic foraminifera dwarfism are reported for the first time in Mexico.

The majority of morphological abnormalities observed in Lepidorbitoides minima include fusion of embryos or juveniles and the development of complex forms resulting from the relationship between reproduction and stressful environmental conditions in the unstable setting where the Cárdenas Formation was deposited. Conical tests and budding of lateral chambers are also observed. These forms are similar to those from early Maastrichtian of Turkey described by Görmüs and Meriç (2000).

Abnormal tests of Lepidorbitoides minima are common in the lower part of the Cárdenas section, and in the upper part of the calcareous succession, the total abundance of individuals decreased. In the upper part planktic foraminifera and abundant red algae indicate that water depth increased.

Planktic foraminiferal assemblages allow us to recognize two zones in the Cárdenas succession: the upper part of the Gansserina gansseri (early Maastrichtian) and the lower part of the Abathomphalus mayaroensis Zone (late Maastrichtian).

The last occurrence of Lepidorbitoides minima was in the upper part of the Gansserina gansseri Zone. This demise was due to changes in the sedimentological conditions as subsidence, sea-level variation, and increasing terrigenous input, which are factors related to the regional Laramide Orogeny.

In late Maastrichtian the planktic foraminifer tests show a size reduction in response to the environmental stress conditions produced by local or/and global perturbations.

The benthic foraminifera associated with the dwarfed planktic forms suggest an outer neritic environment.

\section{Acknowledgments}

This work was supported in part by DGAPA-PAPIIT IN 119208 PROJECT grants. We are indebted to Jose Maria 
Pons (Universidad Autónoma de Barcelona) for providing the samples, and to Margarito Tristán (UASLP, San Luis Potosí) for fieldwork assistance.

We are very grateful to Robert Scott (Precision Stratigraphy \& University of Tulsa), Sara Ballent (Universidad de la Plata) and Eustoquio Molina (Universidad de Zaragoza) for the revision of the manuscript and very valuable suggestions that considerably improved our paper. Two anonymous reviewers are thanked for the critical comments. We thank Muhittin Görmüs (Süleyman Demirel University, Isparta) who revised an earlier version of the manuscript. W. Stinnesbeck (Uni. Heidelberg) is thanked for revising the ms.

We thank Blanca Margarita Ramírez for drawing the map, Iriliana López Caballero for making the plates, Diego Aparicio for preparing numerous thin sections. Carlos Linares took the SEM photos and Barbara Martiny reviewed the English.

\section{References}

Abramovich, S., Almogi, L.A., Benjamini, C., 1998, Decline of the Maastrichtian pelagic ecosystem based on planktic foraminifera assemblage change: Implication for the terminal Cretaceous faunal crisis: Geology, 26, 63-66.

Abramovich, S., Keller, G., 2002, High stress late Maastrichtian paleoenvironment: inferences on planktic foraminifera in Tunisia: Palaeogeography, Palaeoclimatology, Palaeoecology, 178, 145-164.

Abramovich, S., Keller, G., Adatte, T., Stinnesbeck, W., Hottinger, L., Steuben, D., Berner, Z., Ramanivosoa, B., Randriamanantenasoa, A., 2002, Age and paleoenvironment of the Maastrichtian to Paleocene of the Mahajanga Basin, Madagascar: a multidisciplinary approach: Marine Micropaleontology, 47, 17-70.

Abramovich, S., Keller, G., 2003, Planktic foraminifera response to the latest Maastrichtian abrupt warm event: a case of study from South Atlantic DSDP Site 525A: Marine Micropaleontology, 48, 225-249.

Alencáster, G., Omaña, L., Pons, J.M., Torres, J. R., Tristán, M., Vázquez, N., 1999. Late Cretaceous rudists and larger foraminifera from the Cárdenas region, San Luis Potosí México. Fifth International Congress on Rudists, Erlangen-Nürnberg, Erlanger Geologische Abhandlungen, Sonderband 3, p.6.

Alve, E., 1991, Benthic foraminifera reflecting heavy metal pollution in Sorljord, Western Norway: Journal of Foraminiferal Research 21, 1-19.

Alve, E., 1995, Benthic foraminiferal responses to estuarine pollution: A review: Journal of Foraminiferal Research, 25, 190-203.

Amicis, G., 1895, Sopra alcune forme nuove di Foraminiferi del Pliocene Inferiore: Naturali Memorie, Società Toscana di Scienze, 14, 18-30.

Ballent, S.C., Carignano, A.P., 2008, Morphological abnormalities in Late Cretaceous and early Paleocene foraminifer tests (northern Patagonia, Argentina): Marine Micropaleontology, 67, 288-296.

Barrera, E., 1994, Global environment changes preceding the CretaceousTertiary boundary: Early-late Maastrichtian transition: Geology, $22,887-880$.

Boltovskoy, E., 1965, Los Foraminíferos Recientes: Buenos Aires, Argentina, EUDEBA, $505 \mathrm{p}$.

Boltovskoy, E., Wright, R., 1976, Recent Foraminifera: The Hague, the Netherlands, W. Junk, 515 p.

Boltovskoy, E., Sott, D.B., Medioli, E.S., 1991, Morphological variations of benthic foraminiferal tests in response to changes in ecological parameters: a review: Journal of Paleontology, 65, 175-185.
Brade, B.S., Twichett, R.J., 2009, Extinction, Dwarfing, and the Lilliput effect: Palaeogeography, Palaeoclimatology, Palaeoecology, 284, $1-3$.

Bradley, J.S., 1956, A teratological Parafusulina: Journal of Paleontology $30,303-304$

Bradshaw, J.S., 1955, Preliminary laboratory experiments on ecology of foraminiferal populations: Micropaleontology, 1, 351-358.

Butterlin, J., 1971, Contribution à la connaissance de Paléogène marin du Nord-Ouest de la Colombie, basée sur les Macroforaminifères: Eclogae Geologicae Helvetiae, 64, 13-27.

Buzas-Stephens, P., Buzas, M.A., 2005, Population dynamics and dissolution of foraminifera in Nueces Bay, Texas: Journal of Foraminiferal Research, 35, 248-258.

Cann, J.H., De Deckker, P., 1981, Fossil Quaternary and living foraminifera from athalassic (non marine) saline lakes, southern Australia: Journal of Paleontology, 55, 660-670.

Caralp, M.H., 1989, Size and morphology of the benthic foraminifer Melonis barleanum: relationships with marine organic matter: Journal of Foraminiferal Research, 19, 235-245.

Carpenter, W.B., 1856, Researches in the Foraminifera: Royal Society of London, Philosophical Transactions, 146, 547-569.

Cevison, H., Hallock, P., 2007, Anomalous features observe on tests of live Archaiasine foraminifers from the Florida Keys, USA: Journal of Foraminiferal Research, 37, 223-233.

Coccioni, R., Gabbianelli, G.Gentiloni Silverj, D., Fonti, P., Kaminski, M.A., Monechi, S., Tateo, F., 1997, Benthic foraminiferal response to heavy metal pollution in the Goro Lagoon (Italy): First Conference on Application of Micropaleontology in Environmental Sciences, Tel Aviv, Abstracts, 47-48.

Coccioni, R., 2000, Benthic foraminifera as bioindicators of heavy metal pollution: A case from the Goro Lagoon (Italy), in Martin, R.E. (ed.), Environmental Micropaleontology: The Application of Microfossils to Environmental Geology: New York, U.S.A., Kluwer Academic/ Plenum Publishers, 71-103.

Coccioni, R., Luciani, V., 2006, Guembelitria irregularis Bloom at the K-T Boundary: Morphological Abnormalities induced by Impact-related Extreme Environmental Stress, in Cokell, Ch., Gilmour, I., Koeberl, C. (eds.), Biological processes associated with the Impact Events: Berlin, Germany, Springer, 179-196.

Cole, W.S., 1960, Variability in embryonic chambers of Lepidocyclina: Micropaleontology 6, 133-144.

Culver, S., 2003, Benthic foraminifera across the Cretaceous-Tertiary (K-T) boundary: a review: Marine Micropaleontology, 47, 177-226.

Debenay, J-P., Della Patrona, L., Herbland, A., Goguenheim, H., 2009, The impact of easily oxidized material (EOM) on the meiobenthos: Foraminifera abnormalities in shrimp ponds of New Caledonia; implications for environmenta and paleoenvironment survey: Marine Pollution Bulletin, 59, 323-335.

Douvillé, H., 1927, Les Orbitoïdes de la région pétrolifère du Mexique: Comptes Rendues de la Société Géologique de France, 1, 34-35.

Fleury, J. J. Bignot, G., Blondeau, A., Poignat, A.,1985, Biogéographie de foraminifères benthiques téthysiens du Sénonian à l' Éocène Supérieur: Bulletin de la Société Géologique de France, 8, 757-770.

Fontalini, F., Coccioni, R., 2008, Benthic foraminifera for heavy metal pollution monitoring: a case study from the central Adriatic Sea coast of Italy: Estuarine, Coastal and Shelf Science, 76, 404-417.

Frank, T.D., Arthur, M.A., 1999, Tectonic forcing of Maastrichtian oceanclimatic evolution: Paleoceanography, 14, 103-117.

Gary, M., McAffe, R., Wolf. C.L., 1972, Glossary of Geology: Washington, U.S.A., American Geological Institute, 805 p.

Gerstel, J., Thunell, R.C., Zachos, J.G., Arthur, M.A., 1986, The Cretaceous /Tertiary boundary event in the North Pacific: plaktonic foraminiferal results from Deep Sea Drilling Project Site 577, Shatsky Rise: Paleoceanography, 1, 97-117.

Geslin, E., Debenay, J.P., Lesourd, M., 1998, Abnormal wall textures and test deformation in Ammonia beccarii (hyaline foraminifer): Journal of Foraminiferal Research, 28, 148-156. 
Geslin, E., Stouff, V., Debenay, J.P.; Lesourd, M., 2000, Environmental variations and foraminiferal test abnormalities, in Martin, R.E. (ed.), Environmental Micropaleontology: The Application of Microfossils to Environmental Geology: New York, U.S.A., Kluwer Academic/ Plenum Publishers, 191-215.

Geslin, E., Debenay, J.P., Duleba, W., Bonetti, C., 2002, Morphological abnormalities of foraminiferal tests in Brazilian environments: comparison between polluted and non-polluted areas: Marine Micropaleontology 45, 151-168.

Goldhammer, R. K., Johnson, R. K., 1999, Mesozoic sequence stratigraphy and paleogeographic evolution of northeast México, in Bartolino, C., Wilson, J. L. \& Lawton, T. F. (eds.), Mesozoic Sedimentary and Tectonic History of North-Central Mexico: Boulder, Colorado, U.S.A., Geological Society of America Special Paper, 340, 1-58.

Görmüs, M., Meriç, E., 2000, Unusual forms of orbitoidal foraminifera in Maastrichtian of Turkey: Cretaceous Research, 21, 801-812.

Harney, J.N., Hallock, P., Talge, H.K., 1998, Observations on a trimorphic life cycle in Amphistegina gibbosa populations from the Florida Keys: Journal of Foraminiferal Research 28, 141-147.

Hottinger, L., 1997, Shallow benthic foraminiferal assemblages as signals for depth of their depositation and their limitations: Bulletin de la Société Géologique de France, 168, 491-505.

Hottinger, L., 2006, Illustrated glossary of terms used in foraminiferal research (on-line): Museum of Natural History, CH 4001 Basel, Switzerland, available on $<$ http://paleopolis.rediris.es/cg/CG2006_ M02/index.html>.

Ifrim, C., Stinnesbeck, W.,Schafhauser, A., 2005, Maastrichtian shallowwater ammoites of northeastern Mexico: Revista Mexicana de Ciencias Geológicas, 22, 48-64.

Inan, N., Meriç, E., Özgen, N. 1996, A different asexual reproduction in Simplorbites papyraceous (Boobee) samples of Karaçam Highland (Niksar-Türkiye). A1x individuals: Revue de Paleobiologie 15, 449-459.

Kaya, M., 2005, Unusual forms in Omphalocyclus macroporus (Lamarck), Discocyclina, Lepidocyclina and Nummulites Genera from the Maastrichtian, Paleocene, Eocene and Aquitanian of the Elazig Region (Eastern Turkey): Environmental Micropaleontology, Microbiology and Meiobenthology, 2, 143-156.

Keller, G. , 2002, Guembelitria-dominate late Maastrichtian planktic foraminiferal assemblages mimic early Danian in central Egypt: Marine Micropaleontology, 47, 71-99.

Keller, G., 2003, Biotic effects of volcanism and impacts: Earth Planetary Sciences Letters, 215, 249-264.

Keller, G., 2004, Low-diversity, late Maastrictian and early Danian planktic foraminiferal assemblages of the eastern Tethys: Journal of Foraminiferal Research, 34, 49-73

Keller, G., 2005, Biotic effects of late Maastrichtian mantle plume volcanism: implications for impacts and mass extinctions: Lithos, 79, 317-341.

Keller, G., Abramovich, S., 2009, Lilliput effect in late Maastrichtian planktic foraminifera: Response to environmental stress: Palaeogeography, Palaeoclimatology, Palaeoecology, 284, 47-62.

Le Calvez, J., 1938, Recherches sur les foraminifères: Développement et reproduction: Archives de Zoologie Experimentale et Générale, 80, 163-333.

Lidz, L., 1965, Sedimentary environment and foraminiferal parameters: Nantucket Bay, Massachussets: Limnology and Oceanography, 10, 392-402.

Longoria, J.F., Gamper, M., 1974, Two new species of Upper Cretaceous Foraminiferida from the Abathomphalus mayaroensis Zone of Mexico: Micropaleontology, 20, 473-477.

Luciani, V., 2007, Test abnormalities in benthic foraminifera and heavy metal pollution at the Goro Lagoon (Italy): a multi-year history: Geophysical Research Abstracts, 9, 09765.

Madkour, H.A., Ali, M.Y., 2008, Heavy metals in the benthic foraminifera from the coastal lagoons, Red Sea, Egypt: indicators of anthropogenic impact on environment (case study): Environmental Geology, 58, 543-553.
Martínez-Colón, M., Hallock, P., Green-Ruiz, C., 2009, Strategies for using shallow-water benthic foraminifers as bioindicators of potentially toxic elements: A review: Journal of Foraminiferal Research, 39, 278-299.

Meriç, E., 1964, A propos de la reproduction des Orbitoididae: Bulletin of the Mineral Research and Exploration Institute of Turkey, 63, 25-32.

Meriç, E., 1970, Schizogony in Orbitoides apiculatus var. gruenbachensis: Micropaleontology, 16, 227-232.

Meriç, E., 1972, A propos d'une forme teratologique d' Orbitoides cf. medius (d'Archiac): Istambul Üniversitesi Fen Fakültesi Mecmuasi, Series B, 37, 239-243.

Meriç, E., 1973, About the schizogony observed in Discocyclina archiaci (Schlumberger): Revista Española de Micropaleontología, 5, 403408.

Meriç, E., 1979, A different view on the origin of some conical forms of Miogypsinoides dehaarti (Van Der Vlerk): Revista Española de Micropaleontología, 11, 505-508.

Meriç, E., 1992, Twin development in Discocyclinidae: Micropaleontology, 38, 310-312.

Meriç, E., Avsar, N., Görmüs, M., Bergin, F., 2005, Twin and triplet forms of Recent benthic foraminifera from the eastern Aegean Sea, Turkish coast: Micropaleontology, 50, 297-300.

Murray, J.W., 1991, Ecology and Paleoecology of Benthic Foraminifera: Harlow, England, Logman Scientific \& Technical, 380 p.

Myers, E.H., 1935, The life history of Patellina corrugata Williamson a foraminifer: California University Scripps Institute of Oceanography Bulletin 3, 355-392

Myers, R.L., 1968, Biostratigraphy of the Cárdenas Formation (Upper Cretaceous) San Luis Potosí, México: Paleontología Mexicana, $24,89$.

Neumann, M., Poisson, A., 1970, A propos de la reproduction chez Orbitoides media (d'Archiac) : Revue de Micropalèontologie, 13, 122-127.

Nigam, R., Caron, D.A., 2000, Does temperature affect dimorphic reproduction in benthic foraminifera? A culture experiment on Rosalina lee: Current Science, 9, 1105-1106.

Nguyen, D.T., 1980, Remarques sur quelques anomalies du test de "Fusulines", Revue de Micropalèontologie, 23, 116-120.

Omaña, L., Pons, J.M., 2000, The foraminifera assemblage from the Cárdenas Formation (Maastrichtian), San Luis Potosí, Eastern Mexico in $6^{\text {th }}$ International Cretaceous Symposium: Vienna, Austria, University of Vienna, 95.

Omaña, L., Pons, J.M., Alencáster, G., 2008, Latest Cretaceous foraminifera from the Cárdenas Formation, San Luis Potosí, Mexico: Biostratigraphical, paleoenvironmental and paleobiogeographical significance: Micropaleontology, 54, 445-462.

Pflum, C.E., Frerichs, W.E., 1976, Gulf of Mexico deep-water foraminifers: Cushman Foundation for Foraminiferal Research Special Publication, 14, 1-108.

Polodova, I., Schönfeld, J., 2008, Foraminiferal test abnormalities in the Western Baltic Sea. Journal of Foraminiferal Research, 38, 318-336.

Premoli Silva, I., Sliter, W.V., 1995, Cretaceous planktonic biostratigraphy and evolutionary trends from the Bottaccione section, Gubbio, Italy: Paleontographia Italica, 82, 1-89.

Premoli Silva, I.,Verga, D., 2004, Practical Manual of Cretaceous Planktonic Foraminifera. International School on Planktonic Foraminifera, $3^{\text {rd }}$ Course: Cretaceous: Perugia, Italy, Universitie of Perugia and Milan, $283 \mathrm{p}$.

Resig, J.M., 1960, Foraminiferal ecology around ocean outfalls off southern California, in Pearson, P.A. (ed.), Waste disposal in the marine environment: London, England, ,Pergamon Press, 104-121.

Rhumbler, L., 1902, Die Doppelschalen von Orbitolites und anderen Foeraminiferen, vom entwicklungsmechanischen Sttandpunkt aus betrachtet: Archiv für Protistenkunde 1, 193-296.

Rhumbler, L., 1911, Die Foraminiferen (Thalamophoren) der Plankton Expedition, Pt. 1. Die allgemeinen Organizationsverhaltnisse der Foraminiferen. Ergebnisse der Plankton-Expedition der HumboldtStiftung. Lipsius \& Tisher, 3, 1-331. 
Rötger, R., 1974, Larger foraminifera: reproduction and early stages of development in Heterostegina depressa: Marine Biology, 26, 5-12.

Rötger, R., Krüger, R., De Rijk, S., 1990, Trimorphism in Foraminifera (Protozoa)-verification of an old hypothesis, European Journal of Protistology, 25, 226-229.

Samir, A.M., 2000, The response of benthic foraminifera and ostracods to various pollution sources: a study from two lagoons in Egypt: Journal of Foraminiferal Research, 30, 83-98.

Schafhauser,A., Götz, S., Stinnesbeck, W., 2007, Rudist decline in the Maastrichtian Cardenas Formation (East-central Mexico) Palaeogeography, Palaeoclimatology, Palaeoecology, 251, 210-221.

Stouff, V., Debenay, J.P., Lesourd, M. 1999a, Origin of double and multiple tests: observations in laboratory cultures: Marine Micropaleontology, 36, 189-204.

Stouff, V., Debenay, J.P., Lesourd, M. 1999b, Origin of morphological abnormalities in Ammonia (Foraminifera): studies in laboratory and and natural environments: Journal of Foraminiferal Research, $29,152-170$

Urbanek, A., 1993, Biotic crises in the history of Upper Silurian graptoloids: a paleobiological model: Historical Biology, 7, 29-50.

Van Goersel, J.T., 1978, Late Cretaceous orbitoidal Foraminifera, in Hedley, R.H., Adams, C.G. (eds.), Foraminifera: London, England, Academic Press, 3, 1-109.

Venturati, A., 2007, Cretaceous to Early Paleocene Planktonic Foraminifera with twin bilobated and additional last chambers: possible abnormal forms as potential proxies of high environmental stress, in $6^{\text {th }}$ Polish Micropaleontological Workshop “MIKRO-2007”: Gdansk, Poland, Polish Geological Institute, 79-80.
Venturati, A., Baudin, F., 2007, Teratological tests in mid-Cretaceous Planktonic Foraminifera: Inferences from the Pialli Level (OAE 1D) of Monte Pedrano Type Section (Cagli, Central Italy), in $6^{\text {th }}$ Polish Micropaleontological Workshop "MIKRO-2007”: Gdansk, Poland, Polish Geological Institute, 81-83.

Vilela, C.G., Batista, D.S., Baptista-Neto, A., Crapez, M., Mcallister J.J., 2004, Benthic foraminifera in high polluted sediments from Niterói Harbor (Guanabara Bay), Rio de Janeiro, Brazil: Anais da Academia Brasileira de Ciências, 76, 161-171.

Wade, B.S., Olsson, R.K., 2009, Investigation of pre-extinction dwarfing in Cenozoic planktonic foraminifera: Palaeogeography, Palaeoclimatology, Palaeoecology, 284, 39-46.

Wilde, G. L., 1965, Abnormal growth conditions in fusulinids: Contributions from the Cushman Foundation for Foraminiferal Research, 16, 121-124.

Yanko, V., Ahmad, M., Kaminski, M., 1998, Morphological deformities of benthic foraminifera in response to pollution by heavy metals: implications for pollution monitoring: Journal of Foraminiferal Research, 28, 177-200.

Manuscript received: November 9, 2010.

Corrected manuscript received: June 22, 2011.

Manuscript accepted: August 16, 2011. 